\title{
Pengaruh Kemandirian Belajar Terhadap Kemampuan Berfikir Kritis Diintervening Motivasi Belajar E-learning Ekonomi
}

\author{
Khasan Setiaji ${ }^{1}$, Serdiyah Muktiningsih ${ }^{2}$, Nina Farliana ${ }^{3^{*}}$ \\ 1,2,3 Pendidikan Ekonomi Fakultas Ekonomi Universitas Negeri Semarang \\ 1Email: setiaji@mail.unnes.ac.id; ${ }^{2}$ Email: serdiyahmuktiningsih19@gmail.com ; \\ ${ }^{3}$ Email: ninafarliana@mail.unnes.ac.id \\ *Corresponding Author
}

(Received: 26 November 2020; Accepted: 15 Desember 2020; Published: 13 Januari 2021)

\begin{abstract}
This study aimed to analyze the direct and indirect effect of independent learning on critical thinking skills with learning motivation as an intervening variable. This research is a quantitative research with a survey approach. This type of research is ex-post facto. The sampling technique was simple random sampling. The population of this study were all students of class X IPS at SMAN 1 Kragan, Rembang Regency, with a sample of 64 students. The data collection technique used a questionnaire. Data analysis techniques used descriptive analysis and inferential statistical analysis, namely normality test, linearity test, multicolonierity test, heteroscedasticity test, $\mathrm{T}$ test, and path analysis. The results showed that independent learning had positive and significant direct effect on learning motivation by $78.3 \%$. Learning motivation has positive and significant direct effect on critical thinking skills by $61 \%$. Learning independence has positive and significant direct effect on critical thinking skills by $28.9 \%$. Learning independence has positive and significant indirect effect on critical thinking skills with learning motivation as an intervening variable of $47.8 \%$. This shows that independent learning of students who are good and motivation to learn of students is good, it can improve critical thinking skills of good students.
\end{abstract}

Keywords: Independent Learning; Critical Thinking Skills; Motivation to Learn

\begin{abstract}
Abstrak. Tujuan penelitian ini adalah untuk menganalisis pengaruh secara langsung dan tidak langsung kemandirian belajar terhadap kemampuan berpikir kritis dengan motivasi belajar sebagai variabel intervening. Penelitian ini merupakan penelitian kuantitatif dengan pendekatan survei. Jenis penelitan ex-post facto. Teknik pengambilan sampel dengan simple random sampling. Populasi penelitian ini adalah seluruh peserta didik kelas X IPS SMAN 1 Kragan Kabupaten Rembang, dengan sampel sejumlah 64 peserta didik. Teknik pengumpulan data menggunakan angket. Teknik analisis data menggunakan analisis deskriptif dan analisis statatistik inferensial, yaitu uji normalitas, uji linearitas, uji multikolonieritas, uji heteroskedastisitas, uji T, dan analisis jalur (path analysis). Hasil penelitian menunjukkan bahwa kemandirian belajar berpengaruh positif dan signifikan secara langsung terhadap motivasi belajar sebesar 78,3\%. Motivasi belajar berpengaruh positif dan signifikan secara langsung terhadap kemampuan berpikir kritis sebesar $61 \%$. Kemandirian belajar berpengaruh positif dan signifikan secara langsung terhadap kemampuan berpikir kritis sebesar $28,9 \%$. Kemandirian belajar berpengaruh positif dan signifikan secara tidak langsung terhadap kemampuan berpikir kritis dengan motivasi belajar sebagai variabel intervening sebesar 47,8\%. Hal tersebut menunjukkan bahwa kemandirian belajar peserta didik yang baik dan motivasi belajar peserta didik yang baik, maka mampu meningkatkan kemampuan berpikir kritis peserta didik yang baik.
\end{abstract}

Kata Kunci: Kemandirian Belajar; Kemampuan Berfikir Kritis; Motivasi Belajar

\section{PENDAHULUAN}

Sejak terjadinya wabah virus corona (COVID-19) yang melanda lebih dari 200 negara di dunia telah memberikan tantangan tersendiri bagi lembaga pendidikan. Kondisi ini mengharuskan masyarakat termasuk peserta didik dan tenaga pendidik untuk stay at home, bekerja, beribadah dan belajar di rumah
(Jamaluddin, 2020); (Arifa, 2020). Kondisi demikian menuntut lembaga pendidikan untuk melakukan inovasi dalam proses pembelajaran. Salah satu bentuk inovasi tersebut adalah dengan melakukan pembelajaran secara online atau daring (Astini, 2020).

UNICEF, WHO \& IFRC (2020) dalam COVID-19 Prevention and Control in 
Schools menyebutkan bahwa ketika situasi persebaran virus semakin cepat maka sekolah harus ditutup dan proses pendidikan harus tetap berjalan melalui

kegiatan pembelajaran online dengan menggunakan berbagai media (Ismail, 2020). Per tanggal 17 April 2020, diperkirakan 91,3\% atau sekitar 1,5 miliar peserta didik di seluruh dunia tidak dapat bersekolah karena munculnya pandemi COVID19. Dalam jumlah tersebut termasuk di dalamnya kurang lebih 45 juta peserta didik di Indonesia atau sekitar 3\% dari jumlah populasi peserta didik yang terkena dampak secara global (BPS, 2020).

Adapun sisi positif dari permasalahan tersebut adalah peserta didik maupun guru dapat menguasai teknologi untuk menunjang pembelajaran secara online. Di era revolusi 4.0 guru dan peserta didik dituntut untuk memiliki kemampuan dalam bidang teknologi pembelajaran, sehingga peserta didik mampu mengembangkan kemampuan berpikir kritis, kemandirian, kreatifitas dan inovasinya melalui tugas-tugas yang diberikan oleh guru (Theffidy, 2020).

Ada begitu banyak hal yang perlu diperhatikan selama masa pandemi COVID-19. Terkait dengan bagaimana cara mengembangkan minat dan bakat peserta didik serta menumbuhkan kemampuan berpikir kritis melalui kemandirian belajar yang perlu dikembangkan di tengah masa pandemi COVID19 (Papilaya, 2020). Pembelajaran tidak lagi diwujudkan dalam bentuk pembekalan pengetahuan semata, tetapi dalam bentuk peningkatan kebiasaan (ability). Sehingga peserta didik untuk mampu belajar secara mandiri agar mampu bernalar dan berpikir kritis (Brodjonegoro, 2020).

Pada saat belajar peserta didik menggunakan kemampuan berpikir untuk memahami pengetahuan dan memecahkan masalah yang dihadapinya. Sementara kemampuan berpikir peserta didik sangat bergantung pada kualitas dan kuantitas hasil belajar yang diperolehnya. Peserta didik akan mampu berinovasi apabila memiliki pemikiran yang kritis (Lombu'u, 2019). Dalam pembelajaran ekonomi, tujuan dari mata pelajaran ekonomi di SMA, yaitu peserta didik memiliki kemampuan antara lain memahami sejumlah konsep ekonomi untuk mengaitkan peristiwa dan masalah ekonomi dengan kehidupan sehari-hari. Menampilkan sikap ingin tahu diperlukan untuk mendalami ilmu ekonomi. Selanjutnya, membentuk sikap bijak, rasional dan bertanggung jawab dengan memiliki pengetahuan dan keterampilan ilmu ekonomi, manajemen, serta akuntansi yang bermanfaat bagi diri sendiri, rumah tangga, masyarakat, dan negara (Surasa, 2017); (Hadija, 2017); (Murdinar, 2016); (Rachmawati, 2012). Oleh karena itu, keterampilan berpikir peserta didik dalam belajar ilmu ekonomi perlu dikembangkan.

Disamping kemampuan peserta didik dalam berpikir, juga terdapat faktor yang sangat mempengaruhi pencapaian hasil belajar peserta didik, yaitu kemandirian belajar. Peserta didik yang mandiri akan mampu menguasai suatu materi dan mampu memecahkan masalah yang dihadapi. Dalam kemandirian belajar, seorang peserta didik harus proaktif serta tidak tergantung pada guru. Walaupun demikian, kemandirian belajar erat hubungannya dengan motivasi belajar peserta didik (Egok, 2016). Kemandirian belajar dan motivasi belajar yang dimiliki peserta didik mempunyai peran penting dalam membantu peserta didik untuk mencapai keberhasilan belajarnya, dalam hal ini adalah meningkatkan kemampuan berpikir kritisnya (Rifa'i, 2012); (Ku, 2012).

Penelitian-penelitian terdahulu, seperti penelitian yang dilakukan oleh (Yang, 2012); (Sofiya, 2014) dan (Nugraha, 2017) menunjukkan bahwa terdapat pengaruh yang positif secara parsial antara motivasi belajar terhadap berpikir kritis peserta didik. Selanjutnya, penelitian yang dilakukan oleh (Hammer, 2011) dan (Yanwar, 2019) menyimpulkan bahwa semakin tinggi kemandirian belajar peserta didik akan memberikan gambaran adanya kepercayaan diri yang tinggi, maka dapat meningkatkan kemampuan berpikir kritis peserta didik. Beberapa penelitian terdahulu menguatkan bahwa terdapat pengaruh positif dan signifikan kemandirian belajar yang tinggi mampu meningkatkan motivasi belajar ekonomi dengan adanya kemampuan berpikir kritis yang baik.

Hasil observasi yang dilakukan di SMA Negeri 1 Kragan, hasil belajar ulangan harian secara online pada mata pelajaran ekonomi kelas X IPS tahun pelajaran 2019/2020 belum mencapai tingkat ketuntasan yang diharapkan berdasarkan KKM (Kriteria Ketuntasan Minimal yaitu 70). Berdasarkan data nilai ulangan harian secara online mata pelajaran ekonomi peserta didik kelas X IPS SMAN 1 Kragan, diketahui bahwa hasil belajar ekonomi peserta didik kelas $X$ IPS masih tergolong rendah. Peserta didik yang mencapai Kriteria Ketuntasan Minimum (KKM) hanya 80 peserta didik dari jumlah seluruh peserta didik kelas X IPS yaitu sebanyak 177 
peserta didik, atau hanya $45,20 \%$ saja. Sedangkan, 54,80\% sisanya yang berjumlah 97 peserta didik belum mencapai KKM.

Ketidaktuntasan nilai ulangan harian secara online peserta didik kelas X IPS untuk mata pelajaran ekonomi tersebut dikarenakan dipengaruhi beberapa faktor internal, yakni kemampuan berpikir kritis yang dimiliki oleh peserta didik masih rendah, peserta didik masih sangat bergantung pada guru, dan kemandirian belajar masih belum seluruhnya nampak pada diri peserta didik dalam proses pembelajaran secara online. Salah satu sikap yang ditunjukkan peserta didik belum memiliki kemandirian belajar adalah apabila diberikan pekerjaan rumah masih banyak yang belum mengerjakan dan masih banyak yang hanya menyalin pekerjaan dari temannya. Ini artinya bahwa, peserta didik belum memiliki kesadaran untuk menyelesaikan tugas-tugas secara mandiri.

Berdasarkan latar belakang permasalahan yang telah dibahas, maka tujuan penelitian ini adalah untuk menganalisis pengaruh langsung kemandirian belajar terhadap motivasi belajar, menganalisis pengaruh langsung motivasi belajar terhadap kemampuan berpikir kritis, menganalisis pengaruh langsung kemandirian belajar terhadap kemampuan berpikir kritis dan untuk menganalisis pengaruh tidak langsung kemandirian belajar terhadap kemampuan berpikir kritis dengan motivasi belajar sebagai variabel intervening pada pembelajaran e-learning mata pelajaran ekonomi kelas X IPS SMA Negeri 1 Kragan Rembang.

\section{METODE PENELITIAN}

Jenis penelitian ini adalah penelitian kuantitatif ex-post facto. Dikatakan ex-post facto karena penelitian ini mencari pengaruh sebab akibat dari variabel bebas (X) terhadap variabel terikat ( $\mathrm{Z})$ melalui variabel intervening $(\mathrm{Y})$. Dalam penelitian ini, peneliti ingin mencari pengaruh antara variabel-variabel yang diteliti, yaitu kemandirian belajar dan motivasi belajar sebagai variabel intervening terhadap kemampuan berpikir kritis peserta didik.

Populasi penelitian ini adalah seluruh peserta didik kelas X IPS SMAN 1 Kragan Kabupaten Rembang yang berjumlah 177 peserta didik. Penentuan ukuran sampel menggunakan rumus Slovin dengan tingkat kesalahan $10 \%$, sehingga dengan populasi berjumlah 177 peserta didik, maka diperoleh sampel sebanyak 64 peserta didik. Teknik pengambilan sampel yang digunakan adalah probability sampling, dengan teknik simple random sampling, karena seluruh kelas X IPS cenderung homogen untuk mewakili setiap populasinya.

Data yang digunakan dalam penelitian ini adalah data primer. Teknik pengumpulan data menggunakan angket (kuesioner). Teknik analisis data yang digunakan adalah analisis statistik deskriptif serta analisis statistik inferensial yaitu uji normalitas, uji linearitas, uji multikolonieritas, uji heteroskedastisitas, analisis jalur (path analysis), dan uji hipotesis (uji T). Teknik analisis data ini menggunakan program SPSS 22.0.

\section{HASIL DAN PEMBAHASAN}

Hasil perhitungan analisis deskriptif kemandirian belajar mata pelajaran ekonomi, secara keseluruhan tingkat kemandirian belajar peserta didik dalam kriteria yang baik, hal tersebut tercermin dari nilai rata-rata jawaban responden yaitu 169,81. Hasil perhitungan analisis deskriptif kemampuan berpikir kritis mata pelajaran ekonomi dalam kriteria yang baik, hal tersebut tercermin dari nilai rata-rata jawaban responden yaitu 112,95. Sedangkan hasil perhitungan analisis deskriptif motivasi belajar mata pelajaran ekonomi peserta didik dalam kriteria yang baik, hal tersebut tercermin dari nilai rata-rata jawaban responden yaitu 73,36.

Tahap selanjutnya adalah uji normalitas. Uji normalitas data penelitian ini dilakukan dengan menggunakan uji statistik KolmogorovSmirnov (K-S). Berdasarkan uji statistik diperoleh nilai Kolmogorov Smirnov (K-S) sebesar 0,104 dan signifikansi pada 0,085. Karena nilai signifikansi berada di atas 0,05 $(0,085>0,05)$ maka dapat disimpulkan bahwa data residual dengan kemampuan berpikir kritis sebagai variabel endogen berdistribusi normal.

Berdasarkan uji statistik diperoleh nilai Kolmogorov-Smirnov (K-S) dengan motivasi belajar sebagai variabel dependen adalah sebesar 0,102 dan signifikansi pada 0,093. Karena nilai signifikansi berada di atas $0,05(0,093>0,05)$ maka dapat disimpulkan bahwa data residual dengan motivasi belajar sebagai variabel dependen berdistribusi normal. Selain menggunakan uji Kolmogorov-Smirnov (K-S), uji normalitas data juga dilakukan menggunakan Plot of Regression Standardized Residual, dan diperoleh output SPSS titik-titiknya mendekati garis diagonal, maka dapat disimpulkan bahwa model regresi berdistribusi normal. 
Tahap uji selanjutnya adalah uji linearitas regresi, terlihat nilai signifikansi pada linearity untuk kemandirian belajar adalah 0,000. Karena nilai signifikansi $0,000<0,05$ maka dapat dikatakan bahwa antara kemandirian belajar terhadap kemampuan berpikir kritis peserta didik terdapat hubungan yang linear. Nilai signifikansi pada linearity untuk motivasi belajar adalah 0,000 . Karena nilai signifikansi $0,000<0,05$ maka dapat dikatakan bahwa antara motivasi belajar terhadap kemampuan berpikir kritis peserta didik terdapat hubungan yang linear. Nilai signifikansi pada linearity untuk motivasi belajar adalah 0,000. Karena nilai signifikansi $0,000<$ 0,05 maka dapat dikatakan bahwa antara kemandirian belajar terhadap motivasi belajar peserta didik terdapat hubungan yang linear.

Setelah uji linearitis, kemudian dilakukan uji multikolonieritas, denga hasil tidak ada variabel independen yang memiliki nilai tolerance $<0,10$ yang berarti tidak ada korelasi antar variabel independen yang nilainya lebih dari $95 \%$. Hasil analisis tersebut menunjukkan tidak ada satu variabel independen yang memiliki nilai VIF > 10 dan tidak ada variabel independen yang memiliki nilai tolerance $<0,10$. Jadi dapat disimpulkan bahwa tidak ada multikolonieritas antar variabel independen dalam model regresi.

Pengujian selanjutnya adalah uji heteroskedastisitas. Uji heteroskedastisitas menggunakan uji glejser, menunjukkan bahwa variabel kemandirian belajar mempunyai nilai signifikansi di atas 0,05 yaitu 0,010 , sedangkan motivasi belajar mempunyai nilai signifikansi di bawah 0,05 yaitu 0,006. Hal ini dapat disimpulkan bahwa variabel kemandirian belajar terjadi heterokedastisitas $(0,010>0,05)$ pada model regresi ini, sedangkan variabel motivasi belajar tidak terjadi heterokedastisitas $(0,006<$ $0,05)$ pada model regresi ini.

Hasil uji heterokedastisitas motivasi belajar sebagai variabel endogen menunjukkan bahwa variabel kemandirian belajar mempunyai nilai signifikansi di atas 0,05 yaitu 0,518 . Hal ini dapat disimpulkan bahwa variabel kemandirian belajar terjadi heterokedastisitas $(0,518>0,05)$ pada model regresi ini.

Setelah uji asumsi klasik dilakukan, kemudian dilakukan pengujian hipotesis. Pertama, pengaruh kemandirian belajar (X) terhadap motivasi belajar (Y) secara parsial dilakukan dengan menggunakan uji T. Kriteria uji t: $H_{0}$ ditolak jika $t_{\text {hitung }}>t_{\text {tabel }}$ untuk derajat bebas $(\mathrm{df})=\mathrm{n}-\mathrm{k}-1=64-2-1=61$. Berdasarkan tabel 1 distribusi t diperoleh $t_{0,025}$
$(61)=1,9996$. Berdasarkan kriteria tolak $H_{01}$ di atas, nilai $t_{\text {hitung }}(9,909)$ lebih besar jika dibandingkan dengan $t_{\text {tabel }}$ pada tingkat signifikansi $95 \%(\alpha=5 \%)$ sehingga keputusan yang diambil adalah $H_{01}$ ditolak. Dengan demikian dapat disimpulkan bahwa kemandirian belajar berpengaruh langsung positif dan signifikan terhadap kemampuan berpikir kritis peserta didik. Berdasarkan nilai beta (standardized coefficients), besarnya pengaruh kemandirian belajar terhadap kemampuan berpikir kritis sebesar 0,783 . Jika dibuat model persamaan, maka terbentuk struktur model pertama yaitu: $Y=0,783 X+\varepsilon_{1}$.

Kedua, pengaruh motivasi belajar (Y) terhadap kemampuan berpikir kritis $(\mathrm{Z})$ secara parsial dilakukan dengan menggunakan uji $\mathrm{T}$. Berdasarkan kriteria tolak $H_{02}$, nilai $t_{\text {hitung }}$ $(5,733)$ lebih besar jika dibandingkan dengan $t_{\text {tabel }}$ pada tingkat signifikansi $95 \%(\alpha=5 \%)$ sehingga keputusan yang diambil adalah $H_{02}$ ditolak. Dengan demikian dapat disimpulkan bahwa motivasi belajar berpengaruh langsung positif dan signifikan kemampuan berpikir kritis peserta didik. Berdasarkan nilai beta (standardized coefficients), besarnya pengaruh motivasi belajar terhadap kemampuan berpikir kritis sebesar 0,610.

Ketiga, pengaruh kemandirian belajar (X) terhadap kemampuan berpikir kritis $(\mathrm{Z})$ secara parsial dilakukan dengan menggunakan uji t. Nilai $t_{\text {hitung }}(2,714)$ lebih besar jika dibandingkan dengan $t_{\text {tabel }}$ pada tingkat signifikansi 95\% $(\alpha=5 \%)$ sehingga keputusan yang diambil adalah $H_{01}$ ditolak. Dengan demikian dapat disimpulkan bahwa kemandirian belajar berpengaruh langsung positif dan signifikan kemampuan berpikir kritis peserta didik. Berdasarkan nilai beta (standardized coefficients), besarnya pengaruh kemandirian belajar terhadap kemampuan berpikir kritis peserta didik sebesar 0,289.

Keempat, pengaruh kemandirian belajar secara tidak langsung terhadap kemampuan berpikir kritis dengan motivasi belajar sebagai variabel intervening. Berdasarkan pengujian diperoleh hasil bahwa kemandirian belajar signifikan secara langsung mempengaruhi motivasi belajar dan motivasi belajar signifikan mempengaruhi kemampuan berpikir kritis. Persamaan model pada masing-masing struktur disajikan secara detail pada Tabel 1.

Tabel 1. Persamaan Model Struktur Estimasi 


\begin{tabular}{ll}
\hline Model Struktural & $\begin{array}{l}\text { Persamaan Strukrural } \\
\text { Estimasi }\end{array}$ \\
\hline$Y=P_{1} X+\varepsilon_{1}$ & $\mathrm{Y}=0,783 \mathrm{X}+\varepsilon_{1}$ \\
$Z=P_{3} X+P_{2} Y+\varepsilon_{2}$ & $\mathrm{Z}=0,289 \mathrm{X}+0,610 \mathrm{Y}+\varepsilon_{2}$ \\
\hline
\end{tabular}

Sumber: Data primer, diolah tahun 2020

Tabel 2. digunakan untuk membuat dekomposisi pengaruh secara langsung variabel kemandirian belajar dan motivasi belajar terhadap kemampuan berpikir kritis peserta didik dan pengaruh secara tidak langsung kemandirian belajar terhadap kemampuan berpikir kritis melalui motivasi belajar peserta didik.

Tabel 2. Dekomposisi Pengaruh Kemandirian Belajar terhadap Kemampuan Berpikir Kritis dengan Motivasi Belajar

\begin{tabular}{|c|c|c|c|}
\hline $\begin{array}{l}\text { Variabel } \\
\text { Eksogen } \\
\text { (1) }\end{array}$ & $\begin{array}{l}\text { Jenis } \\
\text { Pengaruh } \\
(2) \\
\end{array}$ & $\begin{array}{l}\text { Koefisien } \\
\text { Jalur/ } \\
\text { Pengaruh } \\
\text { (3) }\end{array}$ & $\begin{array}{l}\text { Hasil } \\
\text { Pengujian } \\
\text { (4) } \\
\end{array}$ \\
\hline \multirow{3}{*}{$\begin{array}{l}\text { Kemandiri } \\
\text { an Belajar } \\
\text { (X) }\end{array}$} & Langsung & 0,289 & $\begin{array}{l}\text { Signifikan } \\
\text { (pengujian } \\
\text { ke-3) }\end{array}$ \\
\hline & $\begin{array}{l}\text { Tidak } \\
\text { Langsung } \\
\text { (dengan } \\
\text { motivasi } \\
\text { belajar/Y) }\end{array}$ & 0,478 & $\begin{array}{l}\text { Signifikan } \\
\text { (pengujian } \\
\text { ke-1 dan } \\
\text { ke-2) }\end{array}$ \\
\hline & Total & 0,767 & \multirow{3}{*}{$\begin{array}{l}\text { Signifikan } \\
\text { (pengujian } \\
\text { ke-2) }\end{array}$} \\
\hline \multirow[t]{2}{*}{$\begin{array}{l}\text { Motivasi } \\
\text { Belajar (Y) }\end{array}$} & Langsung & 0,610 & \\
\hline & Total & 0,610 & \\
\hline
\end{tabular}

Sumber: Data primer, diolah tahun 2020

Berdasarkan pada Tabel 2, dapat dilihat bahwa pengaruh kemandirian belajar terhadap kemampuan berpikir kritis sebesae 0,767. Pengaruh ini terdiri dari pengaruh langsung kemandirian belajar terhadap kemampuan berpikir kritis sebesar 0,289 dan pengaruh tidak langsung kompensasi terhadap kemampuan berpikir kritis dengan motivasi belajar sebagai variabel intervening sebesar 0,478. Dengan demikian dapat disimpulkan bahwa pengaruh langsung kemandirian belajar terhadap kemampuan berpikir kritis lebih kecil dari pengaruh tidak langsungnya.

Gambar 1. Hasil Model Analisis Jalur

$$
P_{3}=0,289
$$

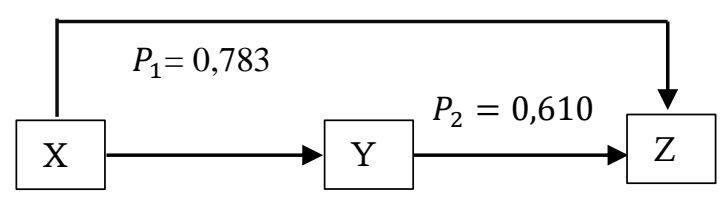

\footnotetext{
Pengaruh Kemandirian Belajar Secara Langsung Terhadap Motivasi Belajar
}

Kemandirian belajar memberikan pengaruh positif dan signifikan secara langsung terhadap motivasi belajar peserta didik kelas $\mathrm{X}$ IPS SMAN 1 Kragan Hasil uji parsial (uji T) dalam penelitian ini menunjukkan bahwa nilai signifikansi variabel kemandirian belajar terhadap motivasi belajar adalah 0,000 yang berarti $<0,05$; maka dapat disimpulkan bahwa Sig $t_{\text {hitung }}<$ Sig 0,05; maka $H_{01}$ ditolak dan $H_{a 1}$ diterima. Dengan demikian, kemandirian belajar akan bepengaruh positif secara langsung terhadap motivasi belajar peserta didik kelas X IPS SMAN 1 Kragan sebesar 78,3\%.

Hasil penelitian tersebut sejalan dengan hasil penelitian (Hidayat, 2014) yang menyatakan bahwa variabel kemandirian belajar memiliki tingkat signifikan sebesar 0,000; dapat disimpulkan bahwa variabel kemandirian belajar berpengaruh signifikan terhadap motivasi belajar karena $0,000 \leq 0,05$. (Mulyaningsih, 2014) menyatakan bahwa terdapat pengaruh positif kemandirian belajar terhadap motivasi belajar ditunjukkan dengan nilai $r_{x 3 y}=0,765 ; r_{x 3 y}^{2}=$ 0,586 . Semakin baik kemandirian belajar yang dimiliki peserta didik, maka akan semakin baik motivasi belajar peserta didik pada pembelajaran e-learning mata pelajaran ekonomi.

\section{Pengaruh Motivasi Belajar Secara Langsung Terhadap Kemampuan Berpikir Kritis}

Motivasi belajar memberikan pengaruh positif dan signifikan secara langsung terhadap kemampuan berpikir kritis peserta didik. Hasil uji parsial (uji T) dalam penelitian ini menunjukkan bahwa nilai signifikansi variabel motivasi belajar terhadap kemampuan berpikir kritis adalah 0,000 yang berarti $<0,05$; maka dapat disimpulkan bahwa Sig $t_{\text {hitung }}<\operatorname{Sig} 0,05$; maka $H_{02}$ ditolak dan $H_{a 2}$ diterima. Besarnya pengaruh motivasi belajar secara langsung terhadap kemampuan berpikir kritis sebesar 0,610. Dengan demikian, pemberian motivasi belajar akan bepengaruh positif secara langsung terhadap kemampuan berpikir kritis peserta didik kelas X IPS SMAN 1 Kragan.

Beberapa penelitian sebelumnya juga memberikan hasil yang tidak berbeda. (Sofiya, 2014); (Bernard, 2008); (Howard, 2015); dan (Fajriaturrohmah, 2019) menyatakan bahwa bahwa motivasi belajar berpengaruh secara langsung terhadap kemampuan berpikir kritis. Dengan demikian penelitian ini sejalan dengan penelitian sebelumnya. Semakin baik motivasi belajar yang dimiliki peserta didik, maka akan semakin baik kemampuan berpikir kritis peserta 
didik pada pembelajaran e-learning mata pelajaran ekonomi.

\section{Pengaruh Kemandirian Belajar Secara Langsung Terhadap Kemampuan Berpikir Kritis}

Kemandirian belajar memberikan pengaruh positif dan signifikan secara langsung terhadap kemampuan berpikir kritis. Hasil uji parsial (uji T) dalam penelitian ini menunjukkan bahwa nilai signifikansi variabel kemandirian belajar terhadap kemampuan berpikir kritis adalah 0,009 yang berarti $<0,05$; maka dapat disimpulkan bahwa Sig $t_{\text {hitung }}<$ Sig 0,05; sehingga $H_{a 3}$ diterima. Pemberian kemandirian belajar akan bepengaruh positif secara langsung terhadap kemampuan berpikir kritis peserta didik kelas X IPS SMAN 1 Kragan sebesar 28,9\%.

Senada dengan hasil penelitian (Kopzhassarova, 2016); (Fajriaturrohmah, 2019) dan (Mulyati, 2020) menyatakan bahwa kemandirian belajar berpengaruh secara langsung terhadap kemampuan berpikir kritis. (Asmar, 2020) dan (Dunne, 2015) menyatakan bahwa nilai kolerasi pearson sebesar $41,2 \%$ menunjukkan kekuatan hubungan antara kemandirian belajar dengan kemampuan berpikir kritis. Dengan demikian dapat disimpulkan bahwa penelitian ini sejalan dengan penelitian sebelumnya. Semakin baik kemandirian belajar yang dimiliki peserta didik, maka akan semakin baik kemampuan berpikir kritis peserta didik pada pembelajaran e-learning mata pelajaran ekonomi.

Pengaruh Kemandirian Belajar Secara Tidak Langsung Terhadap Kemampuan Berpikir Kritis Dengan Motivasi Belajar Sebagai Variabel Intervening

Kemandirian belajar memberikan pengaruh positif dan signifikan secara tidak langsung terhadap kemampuan berpikir kritis dengan motivasi belajar sebagai variabel intervening. Besarnya pengaruh kemandirian belajar secara tidak langsung terhadap kemampuan berpikir kritis dengan motivasi belajar variabel intervening sebesar $47,8 \%$. Hasil ini sejalan dengan hipotesis $H_{4}$ bahwa kemandirian belajar akan memberikan pengaruh positif secara tidak langsung terhadap kemampuan berpikir kritis peserta didik dengan variabel intervening motivasi belajar peserta didik kelas X IPS SMAN 1 Kragan.

Beberapa penelitian sebelumnya juga memberikan hasil yang tidak berbeda. (Luke, 2011) dan (Hidayat, 2014) menyatakan bahwa terdapat pengaruh tidak langsung kemandirian belajar terhadap kemampuan berpikir kritis dengan variabel intervening motivasi belajar. (Assagaf, 2016) menyatakan bahwa terdapat pengaruh tidak langsung kemandirian belajar terhadap kemampuan berpikir kritis dengan variabel intervening motivasi belajar sebesar $\mathrm{p}=$ $0,777<0,005$. Artinya, terdapat pengaruh secara tidak langsung kemandirian belajar terhadap kemampuan berpikir kritis lebih besar jika dibandingkan pengaruh secara langsung pada pembelajaran e-learning mata pelajaran ekonomi kelas X IPS SMAN 1 Kragan.

\section{KESIMPULAN DAN SARAN}

Kesimpulan penelitian menunjukkan bahwa kemandirian belajar berpengaruh positif dan signifikan secara langsung terhadap motivasi belajar pada pembelajaran e-learning mata pelajaran ekonomi sebesar 78,3\%. Motivasi belajar berpengaruh positif dan signifikan secara langsung terhadap kemampuan berpikir kritis pada pembelajaran e-learning mata pelajaran ekonomi sebesar 61\%. Kemandirian belajar berpengaruh positif dan signifikan secara langsung terhadap kemampuan berpikir kritis kritis pada pembelajaran e-learning mata pelajaran ekonomi sebesar 28,9\%. Kemandirian belajar berpangaruh positif dan signifikan secara tidak langsung terhadap kemampuan berpikir kritis dengan motivasi belajar sebagai variabel intervening pada pembelajaran e-learning mata pelajaran ekonomi sebesar $47,8 \%$.

Saran yang penulis ajukan untuk penelitian selanjutnya diharapkan adanya penjabaran indikator dimasing-masing variabel yang tidak hanya berfokus pada kemandirian belajar. Indikator tersebut bisa ditinjau dari self efficacy, status sosial orang tua, pendapatan orangtua, pengaruh teman sebaya, dan lain sebagainya, sehingga ada pengembangan model penelitian yang lebih kompleks.

\section{DAFTAR RUJUKAN}

Anonim. (2020). Data Peserta Didik di Masa Pandemi Covid 19. Jakarta: Badan Pusat Statistik (BPS).

Arifa, F. N. (2020, April). Tantangan Pelaksanaan Kebijakan Belajar Dari Rumah Dalam Masa Darurat COVID-19. Info Singat; Kajian Singkat Terhadap Isu Aktual dan Strategis. Jurnal Bidang Kesejahteraan Sosial. , Vol. XII(No.7/I/Puslit). 
Asmar, A. \&. (2020). Hubungan Kemandirian Belajar terhadap Kemampuan Berpikir Kritis melalui Penggunaan Software Geogebra. Jurnal Program Studi Pendidikan Matematika. Volume 9 Nomor 2, 221-230.

Assagaf, G. (2016). Pengaruh Kemandirian Belajar dan Regulasi Diri terhadap Hasil Belajar Matematika melalui Motivasi Berprestasi pada Siswa Kelas X SMA Negeri di Kota Ambon. Jurnal Matematika dan Pembelajarannya. Volume 2 Nomor 1.

Astini, N. K. (2020). Pemanfaatan teknologi informasi dalam pembelajaran tingkat sekolah dasar pada masa pandemi covid19. Lampuhyang, 11(2), 13-25.

Bernard, R. M. (2008). Exploring the structure of the Watson- Glaser critical thinking appraisal: One scale or many subscales? Thinking Skills and Creativity, 3(1), 1522.

BPS. (2020). Data Peserta Didik Di Masa Pandemi Covid 19. Jakarta: Badan Pusat Statistik (BPS).

Brodjonegoro, S. S. (2020). Pembelajaran Masa Depan yang Tidak Pasti. Akademi Ilmu Pengetahuan Indonesia (AIPI). Diambil kembali dari https://aipi.or.id/frontend/opinion/detail/ $413267415 \mathrm{a} 774 \mathrm{~d} 77$.

Dunne, G. (2015). Beyond critical thinking to critical being: Criticality in higher education and life. International Journal of Educational Research, 71, 86-99. doi:https://doi.org/10.1016/j.ijer.2015. 03.003

Egok, A. S. (2016). Kemampuan Berpikir Kritis dan Kemandirian Belajar dengan Hasil Belajar Matematika. Journal of Chemical Information and Modeling, 53(9), 16891699.

doi:https://doi.org/10.1017/CBO97811 07415324.004

Fajriaturrohmah, R. (2019). Pengaruh Motivasi dan Kemandirian Belajar terhadap Kemampuan Berpikir Kritis Siswa melalui Penerapan Strategi
Pembelajaran Berbasis Masalah. Semarang: Universitas Negeri Semarang.

Hadija, L. (2017). Pengaruh Teman Sebaya dan Prestasi Belajar Ekonomi Terhadap Perilaku Konsumsi Siswa SMA Khadijah Surabaya. Jurnal ekonomi pendidikan dan kewirausahaan, 1(2), 189-201.

Hammer, S. J. (2011). Critical thinking in a first year management unit: The relationship between disciplinary learning, academic literacy and learning progression. Higher Education Research \& Development, 30(3), 303-315.

Hidayat, K. (2014). Motivasi Belajar Sebagai Mediasi Pengaruh Kemandirian Belajar dan Lingkungan Keluarga terhadap Hasil Belajar Mata Pelajaran Produktif Siswa Kelas XI AP SMK N 2 Magelang. Economic Education Analysis Journal (EEAJ). Volume 3 Nomor 3.

Howard, L. W. (2015). Teaching critical thinking skills: Ability, motivation, intervention, and the Pygmalion effect. Journal of Business Ethics, 128(1), 133-147.

Ismail, E. (2020). PENGEMBANGAN MODEL PEMBELAJARAN TECHNOPRENERSHIP BERBASIS ELEARNING DI ERA PANDEMI COVID-19. Jurnal Inovasi Pembelajaran Karakter, 5(3).

Jamaluddin, D. R. (2020). Pembelajaran Daring Masa Pandemik Covid-19 Pada Calon Guru : Hambatan, Solusi dan Proeksi. Karya Tulis Ilmiah UIN Sunan Gunung Djjati Bandung, pp. 1-10.

Kopzhassarova, U. A. (2016). Enhancement of Students' Independent Learning through Their Critical Thinking Skills Development. International Journal of Environmental and Science Education, 11(18), 11585-11592.

$\mathrm{Ku}, \mathrm{L}$. D. (2012). Are materialistic teenagers less motivated to learn? Cross-sectional and longitudinal evidence from the United Kingdom and Hong Kong. Journal of Educational Psychology, 104(1), 74-86.

Lombu'u, R. M. (2019). Pengaruh Kemampuan Berpikir Kritis dan Kemandirian Belajar terhadap Hasil Belajar Fisika Peserta 
Didik SMA Negeri 2 Gowa. Makassar: Universitas Negeri Makassar.

Luke, B. \&. (2011). Developing and enhancing independent learning skills. Accounting Research Journal, 24(3), pp. 290-310.

Mulyaningsih, I. E. (2014). Pengaruh interaksi sosial keluarga, motivasi belajar, dan kemandirian belajar terhadap prestasi belajar. Jurnal Pendidikan dan Kebudayaan, 20(4), 441-451.

Mulyati, S. J. (2020). Creative Critical Thinking Skill Reviewed by Curiosity on Independent Learning Assisted by ELearning. Unnes Journal of Mathematics Education Research, 208-214.

Murdinar, H. E. (2016). Pembelajaran Ekonomi Untuk Meningkatkan Perilaku Produktif Siswa SMA. In National Conference on Economic Education.

Nugraha, A. J. (2017). Analisis kemampuan berpikir kritis ditinjau dari keterampilan proses sains dan motivasi belajar melalui model PBL. Journal of Primary Education, 6(1), 35-43.

Papilaya, P. M. (2020). Membangun Karakter Peserta Didik di Tengah Pandemi Covid19; Menjawab Kebutuhan Kreatif Positif Berbasis Musik. Diambil kembali dari https://www.satumaluku.id/2020/05/01/

Rachmawati, D. (2012). Implementasi Standar Isi (SI) mata pelajaran ekonomi SMA berdasarkan persepsi guru ekonomi SMA Negeri di Kota Malang. Malang: Doctoral dissertation, Universitas Negeri Malang.
Rifa'i, A. \&. (2012). Psikologi Pendidikan. Semarang: UPT UNNES Press.

Sofiya, N. R. (2014). Pengaruh Motivasi Belajar, Membaca Kritis Dan Cara Belajar Terhadap Berpikir Kritis Siswa Jurusan Administrasi Perkantoran SMK Widya Praja Ungaran. Economic Education Analysis Journal, 3(3).

Statistik, B. P. (2020). Data Peserta Didik Di Masa Pandemi Covid 19. Jakarta: Badan Pusat Statistik (BPS).

Surasa, N. N. (2017). Proses belajar siswa dalam meningkatkan kemampuan berpikir kritis mata pelajaran ekonomi SMA. Jurnal Pendidikan: Teori, Penelitian, dan Pengembangan, 2(1), 78-84.

Theffidy, S. G. (2020, Maret 30). Pendidikan Era Revolusi Industri 4.0 di Tengah COVID19. Diambil kembali dari https://ombudsman.go.id/artikel/r/artikel --pendidikan-era-revolusi-industri-40-ditengah-covid-19

Yang, Y. T. (2012). Digital storytelling for enhancing student academic achievement, critical thinking, and learning motivation: A year-long experimental study. Computers \& education, 59(2), 339-352.

Yanwar, A. \&. (2019). Analisis Kemampuan Berpikir Kritis Matematis: Dampak Pendekatan Saintifik ditinjau dari Kemandirian Belajar. Desimal: Jurnal Matematika, 2(1), 9-22. 